AL-MASHRAFIYAH: Jurnal Ekonomi, Keuangan, dan Perbankan Syariah

ISSN (p): 2597-4904 ISSN (e) : 2620-5661

Volume 3, Nomor 2, Oktober (2019), h.128-139

https://doi.org/10.24252/al-mashrafiyah.v3i2.10038

\title{
FAKTOR-FAKTOR YANG MEMPENGARUHI KUALITAS PENYAJIAN LAPORAN KEUANGAN SYARIAH BAITUL MAAL WA TAMWIL DI KABUPATEN WONOGIRI
}

\author{
Risky Yuniar Rahmadieni \\ Pasca Sarjana Ekonomi Syariah, UIN Sunan Kalijaga Yogyakarta \\ rrahmadieni@gmail.com
}

\begin{tabular}{|c|c|}
\hline Keywords: & ABSTRACT \\
\hline Islamic & Baitul Mal Wattamwil is a sharia financial institution that develops business activities \\
\hline Accounting & and prepares financial reports with sharia principles. Shariah accounting standards, \\
\hline Standards, & shariah audit, shariah supervision, Islamic corporate governance and Islamic work ethics \\
\hline Shariah Audit & are instrumental factors in the preparation of quality financial statements. The purpose \\
\hline and Shariah & of this study was to determine the extent to which the Statement of Islamic Accounting \\
\hline Financial Report & $\begin{array}{l}\text { Standards, Shariah Audit, Shariah Supervision, Islamic Corporate Governance and } \\
\text { Islamic Work Ethos affect the Quality of Shariah Financial Statement Presentation in } \\
\text { the Baitul Wat Mal of Wonogiri Regency Regional Office. This study uses a } \\
\text { quantitative approach. Samples were taken by convenience sampling method. Based on } \\
\text { the results of this study, effects of statement of Islamic accounting standards and Islamic } \\
\text { work ethos on the quality presentation of Islamic financial statements. On the other } \\
\text { band, Islamic auditing, shariah supervision, Islamic corporate governance can not affect } \\
\text { the quality presentation of sharia financial statements. }\end{array}$ \\
\hline Kata Kunci: & ABSTRAK \\
\hline & Baitul Mal Wattamwil merupakan lembaga keuangan syariah yang \\
\hline Akuntansi & mengembangkan kegiatan usahanya dan penyusunan laporan keuangan \\
\hline Syariah, Audit & dengan prinsip-prinsip syariah. Standar akuntansi syariah, audit syariah, \\
\hline Syariah, dan & pengawasan syariah, Islamic corporate governance dan etos kerja Islam adalah \\
\hline & faktor instrumen yang berfungsi membantu dalam menyusun laporan \\
\hline & keuangan yang berkualitas. Tujuan dari penelitian ini adalah untuk \\
\hline Syariah & $\begin{array}{l}\text { mengetahui seberapa besar pengaruh pernyataan standar akuntansi syariah, } \\
\text { audit syariah, pengawasan syariah, Islamic corporate governance dan etos kerja } \\
\text { Islam terhadap kualitas penyajian laporan keuangan syariah di Baitul Mal } \\
\text { Wat Tamwil Kabupaten Wonogiri. Penelitian ini menggunakan pendekatan } \\
\text { kuantitatif. Sampel diambil dengan metode convenience sampling. Dari hasil } \\
\text { penelitian ini, ditunjukkan bahwa menurut uji parsial, terdapat pengaruh } \\
\text { pernyataan standar akuntansi syariah dan etos kerja Islam terhadap kualitas } \\
\text { penyajian laporan keuangan syariah. Di sisi lain, audit syariah, pengawasan } \\
\text { syariah, Islamic corporate governance terdapat tidak berpengaruh terhadap } \\
\text { kualitas penyajian laporan keuangan syariah. }\end{array}$ \\
\hline
\end{tabular}

\section{PENDAHULUAN}

Kabupaten Wonogiri merupakan suatu wilayah yang berada di kawasan eksKaresidenan Surakarta yang biasa disebut dengan Subosukawonosraten. Sejak didirikannya perbankan Islam yang diberi nama Bank Muamalat Indonesia (BMI) pada bulan mei 1992, kemudian menjamurnya Baitul Maal Wattamwil (BMT). Baitul Maal Wattamwil (BMT) 
Risky Yuniar Rahmadieni. Faktor-Faktor Yang Mempengaruhi Kualitas...

merupakan lembaga keuangan syariah yang mengembangkan kegiatan usahanya dengan prinsip-prinsip syariah. Peran BMT menjadi salah satu lembaga keuangan syariah yang melindungi masyarakat menengah ke bawah dari sistem bunga yang diterapkan oleh lembaga keuangan konvesional.

Kasus BMT Sabilillah, nasabah yang telah berinventasi tidak bisa mencairkan dana deposito dengan berbagai alasan. Total deposito maupun tabungan yang masih tertahan $\mathrm{Rp}$ 8,75 miliar dengan sekitar 270 nasabah. Akibatnya BMT Sabilillah Slogohimo mengalami kebangkrutan dengan nilai kerugian sebesar Rp 16,9 milliar (kawul, 2017).

Kepala Dinas Koperasi UMKM Perdagangan dan Perindustrian Wonogiri Guruh Santosa mengaku kecolongan atas permasalahan tersebut. Sebab, selama ini manajemen BMT Sabilillah selalu melaporkan kondisi keuangannya dalam keadaan baik. Namun kenyataan, BMT Sabilillah Slogohimo Wonogiri dalam laporan keuangannya tidak transparan. Laporan ke dinas bagus, hasil audit juga bagus. Seteleh ditelurusi hasil laporan keuangan syariah tidak sesuai kenyataan. (Iwan kawul, 2017).

Selain itu BMT Surya Asri Eromoko, ratusan nasabah tidak dapat mengambil uang tabungannya yang kisaran berjumlah sekitar Rp 13 milliar. Hal ini disebabkan BMT Surya Asri mengalami kemacetan dana kas karena nasabah sering menunggak dan sulit membayar pinjaman hutang. (Heryanto, 2018).

Kualitas laporan keuangan adalah sejauh mana laporan keuangan yang disajikan menunjukan informasi yang benar dan jujur. Kualitas Laporan keuangan (financial statement) adalah hasil akhir dari proses kegiatan akuntansi atau suatu ringkasan dari transaksi keuangan. Laporan keuangan memiliki kualitas tinggi apabila memenuhi persyaratan kualitatif laporan keuangan. Menurut KDPPLKS paragraf 45- 63, karakteristik kualitatif laporan keuangan yaitu relevan, andal, dapat dibandingkan, dan dapat dipahami.

Tujuan laporan keuangan bank adalah memberi informasi tentang posisi keuangan, kinerja, perubahan ekuitas, arus kas dan informasi lainnya yang bermanfaat bagi pengguna laporan keuangan dalam pengambilan keputusan ekonomi serta pertanggungjawaban manajemen atas penggunaan sumber daya yang dipercayakan (Ismail, 2009).

Proses penyajian laporan keuangan syariah harus sesuai standar akuntansi syariah yang dijadikan solusi dalam menjaga akuntabilitas laporan keuangan. Standar Akuntansi Syariah merupakan pernyataan yang diterapkan dalam penyajian laporan keuangan entitas syariah. Maka laporan keuangan syariah BMT disusun dan disajikan sesuai dengan Pernyataan Standar Akuntansi Keuangan (PSAK No.101). Seperti hasil penelitian Susfayetti dan Sri Rahayu (2010) mengatakan bahwa BMT Al-Ishlah Achmad Hizazi, sudah sesuai dengan prinsip-prinsip akuntansi syariah (PSAK) dalam laporan keuangan syariah.

Kebutuhan atas kepastian pemenuhan syariah ini mendorong munculnya fungsi audit baru, yaitu audit syariah. Hasil audit nantinya akan memberikan opini atau pendapat apakah hal-hal yang berkenaan dengan laporan keuangan telah disajikan secara wajar dan sesuai dengan prinsip dan standar yang berlaku umum.

Auditor syariah memegang peranan kursial untuk memastikan akuntabilitas laporan keuangan dan pemenuhan aspek syariah. Audit syariah juga harus memastikan kebenaran, keadilan dan relevansi laporan keuangan. (Mardiyah, 2015). Namun, peran auditor syariah saat ini belum sepenuhnya menguasai ilmu akuntansi ataupun auditing secara syariah. Melihat realisasi bahwa latar belakang pendidikan auditor internal berasal dari ilmu konvesional. Menurut penelitian yang dilakukan Mulyani (2007), seorang auditor harus memiliki kualifikasi di bidang akuntansi yang kemudian memiliki sertifikat spesialisasi dalam bidang auditing syariah.

Dewan Pengawas Syariah (DPS) memiliki peran utama dalam mengawasi operasional jalannya BMT terhadap kepatuhan syariah. Pemeriksaan kepatuhan syariah hanya dilakukan oleh DPS dituntut untuk memiliki kualifikasi keilmuan lembaga keuangan syariah. Hasil penelitian Suazhari dan Rohamawati juga menunjukkan (2015) peran Dewan Pengawas Syariah 
memberikan pengaruh yang signifikan terhadap kualitas laporan keuangan.

BMT juga perlu memerlukan tata kelola baik untuk menyajikan kualitas laporan keuangan. Islamic Corporate Governance (ICG) adalah sebuah pengembangan dari konsep Corporate Governance secara konvensional diantaranya akuntabilitas, tanggung jawab, transparansi, ketepatan, integritas dan kompetensi. Islamic Corporate Governance adalah instasi atau lembaga keuangan yang berlandaskan prinsip-prinsip syariah Islam. Menurut penelitian Nugroho (2015), BMT harus mereformasi dirinya dengan mengimplementasikan Islamic Corporate Governance.

Pelaporan keuangan pada dasarnya yang perlu diperbaiki adalah etos kerja para karyawan. Penyusun laporan keuangan syariah sesuai dengan apa nilai yang ada dalam pikiran mereka. Perilaku beretika Islam dalam bekerja mempengaruhi sumber daya manusia membuat dan menyusun laporan keuangan syariah secara berkualitas. Hasil penelitian Sudarman (2017), mengatakan bahwa etika kerja Islam terdapat pengaruh positif dan signifikan implementasi terhadap kualitas penyajian laporan akuntansi.

\section{LANDASAN TEORI}

\section{Laporan Keuangan Syariah}

Menurut Baridwan (2004), laporan keuangan adalah ringkasan dari suatu proses pencatatan, merupakan suatu ringkasan dari transaksi-transaksi keuangan yang terjadi selama tahun buku yang bersangkutan, yang dibuat oleh manajemen dengan tujuan untuk mmepertanggungjawabkan tugas-tugas yang dibebankan hanya untuk para pemilik. Di dalam aturan Islam mewajibkan transaksi-transaksi keuangan dengan pencatatan secara jujur dan benar. Allah SWT berfirman :

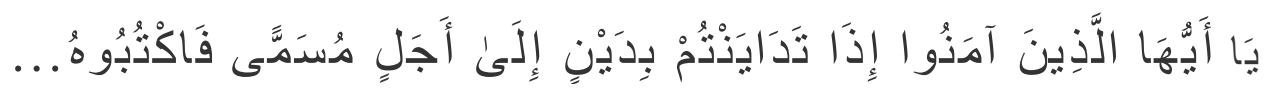

Terjemahnya: Hai orang-orang yang beriman, apabila kamu bermu'amalah tidak secara tunai untuk. waktu yang ditentukan, hendaklah kamu menuliskannya...(QS. Al-Baqarah Ayat 282).

Karakteristik kualitas merupakan ciri khas yang membuat informasi dalam laporan keuangan berguna bagi pemakai. Menurut Kerangka Dasar Penyusunan dan Penyajian Laporan Keuangan Syariah berikut empat karakteristik kualitas pokok yaitu : suatu informasi yang bermanfaat apabila dengan mudah dipahami oleh pihak pengguna, memiliki kemampuan yang relevan untuk mempengaruhi keputusan ekonomi pemakai dengan membantu mereka mengevaluasi masa lalu, masa kini, masa depan, keandalan informasi dalam laporan keuangan bebas dari pengertian yang menyesatkan dan kesalahan yang material dan disajikan secara jujur, informasi yang termuat dalam laporan keuangan akan lebih berguna jika dapat dibandingkan dengan laporan keuangan entitas syariah antar periode untuk mengidentifikasi kecenderungan posisi dankinerja keuangan. Sesuai dengan karakteristiknya, laporan keuangan entitas syariah antara lain :

a. Komponen laporan keuangan yang mencerminkan kegiatan komersial. Komponen laporan posisi keuangan, laporan laba rugi, laporan arus kas dan laporan perubahan ekuitas.

b. Komponen laporan keuangan yang mencerminkan kegiatan sosial. Komponen ini meliputi laporan sumber dan penggunaan dana zakat serta laporan sumber dan penggunaan dana kebajikan.

c. Komponen laporan keuangan lainnya yang mencerminkan kegiatan dan tanggung jawab khusus entitas syariah tersebut. 
Risky Yuniar Rahmadieni. Faktor-Faktor Yang Mempengaruhi Kualitas...

\section{Standar Akuntansi Syariah}

Standar akuntansi syariah merupakan Pernyataan Standar Akuntansi Keuangan (PSAK) Syariah yang ditujukan untuk entitas yang melakukan transaksi syariah baik entitas lembaga syariah maupun lembaga non syariah. Standar yang digunakan untuk entitas yang memiliki transaksi syariah atau entitas berbasis syariah. Informasi yang dihasilkan dan dibutuhkan oleh perbankan syariah termasuk BMT secara lengkap menurut PSAK Nomor101 antara meliputi :

1. Neraca. Meliputi aktiva, kewajiban, investasi pihak ketiga, dan ekuitas. Termuat juga didalamnya saldo akhir dana zakat, infak dan sadaqah (ZIS) serta saldo investasipada sektor riil.

2. Laporan Laba Rugi/Perhitungan Hasil Usaha. Meliputi penghasilan dan beban yang timbul pada sektor jasa keuangan ditambah dengan penghasilan bersih sektor riil.

3. Laporan Arus Kas. Meliputi aktivitas operasi, investasi dan aktivitas pendanaan.

4. Laporan Perubahan Ekuitas. Laporan perubahan ekuitas menggambarkan jumlah keuntungan dan kerugian yang berasal dari kegiatan perusahaan selama periode yang bersangkutan.

5. Laporan Perubahan Dana Investasi Terikat . Laporan perubahan dana investasi terikat memisahkan dana investasi terikat berdasarkan sumber dana dan memisahkan investasi berdasarkan jenisnya. Dalam investasi terikat, BMT hanya bertindak sebagai manajer investasi berdasarkan mudharobah muqayyadah atau sebagai agen investasi.

6. Laporan Sumber dan Penggunaan Dana Zakat, Infaq, Sedekah. Meliputi sumber perolehan, penyaluran kepada yang berhak, dan perubahan saldonya.

\section{Audit Syariah}

Audit syariah dapat dimaknai sebagai suatu proses untuk memastikan bahwa aktivitas-aktivitas yang dilakukan oleh institusi tersebut. Allah SWT berfirman :

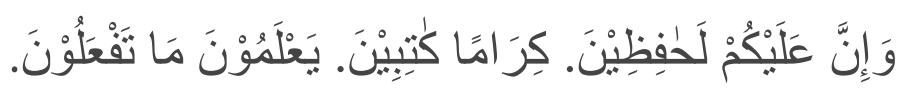

Terjemahnya: Dan sesunggubnya bagi kamu ada (malaikat-malaikat) yang mengawasi (pekerjaanmu), yang mulia (di sisi Allah) dan yang mencatat (amal perbuatanmu), mereka mengetahui apa yang kamu kerjakan (QS. Al-Infithar Ayat 10-12).

Hal-hal yang unsur-unsur dilakukan pada audit lembaga keuangan syariah meliputi : Pengungkapan kewajaran penyajian laporan keuangan dan unsur kepatuhan syariah, memeriksa akunting dalam aspek produk, baik sumber dana ataupun pembiayaan, pemeriksaan distribusi profit, pengakuan pendapatan cash basis secara riil, pengakuan beban secara accrual basis, dalam hubungan dengan bank koresponden depositori, pengakuan pendapatan dengan bagi hasil, pemeriksaan atas sumber dan penggunaan zakat, dan ada tidaknya transaksi yang mengandung unsur-unsur yang tidak sesuai dengan syariah

\section{Pengawasan Syariah}

Pengawasan lembaga keuangan syariah agar lembaga tersebut senantiasa mengikuti aturan dan prinsip-prinsip syariah oleh suatu badan yang diberi wewenang untuk melakukan supervisi yaitu Dewan Pengawas Syariah (DPS). Dewan pengawas syariah merupakan satu dewan pakar ekonomi dan ulama yang menguasai bidang fiqh mu'amalah (Islamic commercial jurisprudence) yang berdiri sendiri dan bertugas mengamati dan mengawasi operasional bank dan semua produk-produknya agar sesuai dengan ketentuan- ketentuan syariat Islam. 


\section{Islamic Corporate Governance}

Islamic Corporate Governance (ICG) adalah sebuah pengembangan dari konsep Corporate Governance secara konvensional. Tujuan utama Islamic Corporate Governance adalah Maqasid Shariah yang merujuk pada kesejahteraan masyarakat (Hasan, 2008).

\section{Etos Kerja Islam}

Kata etos (ethos), berasal dari bahasa yunani yang berarti sikap, kepribadian, watak, karakter. Etos dibentuk oleh berbagai kebiasaan, pengaruh budaya, serta sistim nilai yang diyakininya. Dari kata etos dikenal pula kata etika, etiket, yang terkandung makna semangat untuk mengerjakan sesuatu secara optimal dengan menghindari segala kerusakan, sehingga setiap pekerjaan yang dilakukannya akan diarahkan dalam mengurangi bahkan menghilangkan cacat dari hasil pekerjaannya.

\section{METODE PENELITIAN}

Penelitian ini menggunakan pendekatan kuantitatif. Teknik analisis yang digunakan SPSS Versi 23. Data merupakan data berskala likert dengan sebanyak 35 kuesioner Sampel diambil dengan metode convenience sampling.. Objek penelitian meliputi 5 BMT yang berlokasi kurang lebih $10 \mathrm{~km}$ dari Kantor Bupati Wonogiri yang terdiri dari tiga kecamatan yaitu Kecamatan Selogiri, Wonogiri dan Ngadirojo. Variabel penelitian ini meliputi 12 indikator PSAK, 16 indikator audit syariah, 8 indikator pengawasan syariah, 3 indikator ICG, 8 indikator etos kerja Islam dan 27 indikator kualitas laporan keuangan syariah.

\section{HASIL DAN PEMBAHASAN}

Data hasil penelitian dari angket menunjukkan uji validitas, uji realibilitas uji asumsi klasik dan uji hipotesis. Berikut perhitungannya :

\section{Uji Validitas}

Uji validitas merupakan suatu ukuran yang menunjukkan tingkat keandalan atau keabsahan suatu alat ukur (Ghozali, 2016). Uji validitas dalam penelitian ini dapat diketahui bahwa hubungan antar inter yaitu :

a. Variabel Pernyataan Standar Akuntansi Syariah (PSAK) karena nilai signifikan butir pertanyaan item 1 sampai item 20 lebih besar dari $r$ tabel 0,334 dinyatakan valid.

b. Variabel Audit Syariah dinyatakan valid, karena nilai signifikan butir pertanyaan item 1 sampai item 15 lebih besar dari $\mathrm{r}$ tabel 0,334 dinyatakan valid.

c. Variabel Pengawasan Syariah dinyatakan valid, karena nilai signifikan butir pertanyaan item 1 sampai item 615 lebih besar dari $r$ tabel 0,334 dinyatakan valid.

d. Variabel Islamic Corporate Governance dinyatakan valid, karena nilai signifikan butir pertanyaan item 1 sampai item 4 lebih besar dari $r$ tabel 0,334 dinyatakan valid.

e. Variabel Etos Kerja Islam dinyatakan valid, karena nilai signifikan butir pertanyaan item 1 sampai item 8 lebih besar dari $r$ tabel 0,334 dinyatakan valid.

f. Variabel dependen Kualitas Penyajian Laporan Keuangan Syariah dinyatakan valid, karena nilai signifikan butir pertanyaan item 1 sampai item 20 lebih besar dari $r$ tabel 0,334 dinyatakan valid.

\section{Uji Realibilitas}

Uji realibilitas adalah alat untuk mengukur kuesioner yang merupakan indikator dari variabel atau konstruk (Ghozali, 2016). 
Risky Yuniar Rahmadieni. Faktor-Faktor Yang Mempengaruhi Kualitas...

Tabel 1. Uji Realibilitas

\begin{tabular}{clcccc}
\hline No & \multicolumn{1}{c}{ Variabel } & $\mathbf{r}_{\text {alpha }}$ & $\mathbf{r}_{\text {kritis }}$ & Keterangan \\
\hline 1 & Pernyataan Standar & Akuntansi & 0,772 & 0,60 & Realibel \\
& $\begin{array}{l}\text { Syariah (X1) } \\
2\end{array}$ & Audit Syariah (X2) & 0,790 & 0,60 & Realibel \\
3 & Pengawasan Syariah (X3) & 0,781 & 0,60 & Realibel \\
4 & Islamic Corporate Governance & 0,778 & 0,60 & Realibel \\
& (X4) & 0,776 & 0,60 & Realibel \\
5 & Etos Kerja Islam (X5) & 0,756 & 0,60 & Realibel \\
6 & Kualitas Penyajian & Laporan & & \\
\hline
\end{tabular}

Sumber: Data sekunder setelah diolah, Tabun 2019

Berdasarkan pada Tabel 1 dapat diketahui bahwa butir-butir pertanyaan dari setiap variabel yaitu pernyataan standar akuntansi syariah (X1) sebesar 0,772, Audit Syariah (X2) sebesar 0,790, pengawasan syariah (X3) sebesar 0,781, Islamic Corporate Governance (X4) sebesar 0,778 , etos kerja Islam (X5) sebesar 0,776 dan kualitas penyajian laporan keuangan syariah (Y) sebesar 0,756 dikatakan realibel karena nilai Alpha Croncbach dari setiap variabel lebih besar dari 0,60 .

\section{Uji Asumsi Klasik}

a. Uji normalitas

Uji normalitas bertujuan untuk menguji apakah dalam model regresi, variabel pengganggu atau residual memiliki distribusi normal (Ghozali, 2016). Uji normalitas dalam penelitian ini dapat diketahui bahwa nilai Asymp. Sig. 0,200 lebih besar dari 0,05 sehingga dapat disimpulkan bahwa model regresi terdistribusi normal.

b. Uji Heteroskedasitisitas.

Uji heteroskedasitisitas bertujuan menguji apakah dalam model regresi terjadi ketidaksamaan variance dari residual satu pengamatan ke pengamatan yang lain. Jika variance dari residual satu pengamatan ke pengamatan lain tetap, maka disebut homoskedastisitas dan jika berbeda disebut heteroskedasitisitas (Ghozali, 2016). Hasil pengujian heteroskedasitisitas dapat ditunjukkan pada gambar 2, berikut :

\section{Gambar 1. Uji Heteroskedasitisitas}

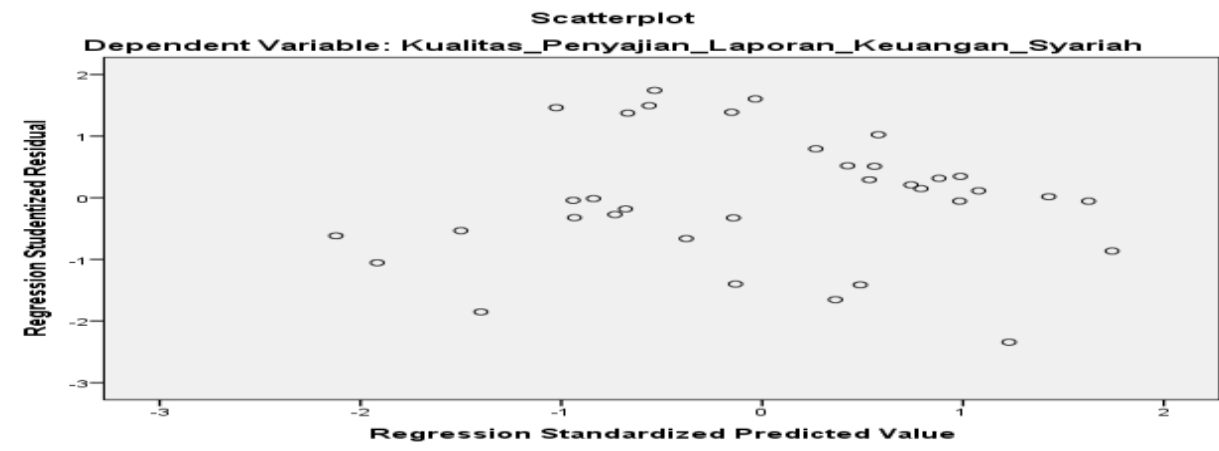

Sumber: Data sekunder setelah diolah, Tabun 2019

Berdasarkan Gambar 1, terlihat data residual berupa titik-titik menyebar secara acak dan tidak membentuk pola tertentu. Dengan demikian dapat disimpulkan model regresi yang diajukan dalam penelitian ini tidak terjadi gejala 
AL-MASHRAFIYAH: Jurnal Ekonomi, Keuangan, dan Perbankan Syariah Volume 3, Nomor 2, Oktober 2019

heteroskedasitisitas yaitu varians residual dari residual satu pengamatanm ke pengamatan yang lain tetap (homokedasitisitas).

c. Uji Multikolinearitas

Uji multikolinearitas bertujuan untuk menguji apakah model regresi ditemukan adanya korelasi antar variabel bebas independen (Gzohali, 2016).

Tabel 2. Uji Multikolinearitas

\begin{tabular}{lcccc}
\hline \multicolumn{1}{c}{ Variabel } & VIF & Cut off & Tolerance & Cut Off \\
\hline PSAK & 1,067 & 10 & 0,938 & 0,01 \\
Audit Syariah & 3,447 & 10 & 0,288 & 0,01 \\
Pengawasan Syariah & 3,515 & 10 & 0,284 & 0,01 \\
ICG & 2,809 & 10 & 0,356 & 0,01 \\
Etos Kerja Islam & 3,547 & 10 & 0,280 & 0,01 \\
\hline
\end{tabular}

Sumber: Data sekunder setelah diolah, Tahun 2019

Berdasarkan Tabel 2, terlihat data variabel pernyataan standar akuntansi syariah $\left(\mathrm{X}_{1}\right)$ nilai VIF sebesar 1,067 dan nilai tolerance sebesar 0,983 , audit syariah $\left(\mathrm{X}_{2}\right)$ nilai VIF sebesar 3,447 dan nilai tolerance sebesar 0,288, pengawasan syariah $\left(\mathrm{X}_{3}\right)$ nilai VIF sebesar 3,515 dan nilai tolerance sebesar 0,284, Islamic Corporate Governance $\left(\mathrm{X}_{4}\right)$ nilai VIF sebesar 2,809 dan nilai tolerance sebesar 0,356 dan etos kerja Islam $\left(\mathrm{X}_{5}\right)$ nilai VIF 3,547 dan nilai tolerance sebesar 0,9280. Dengan demikin keempat variabel independen tersebut nilai VIF lebih dari 10 dan nilai Tolerance kurang dari 0,10 maka tidak terjadi gejala multikolinearitas.

d. Uji Autokorelasi

Uji autokorelasi bertujuan untuk menguji apakah dalam model regresi ada korelasi antara kesalahan penganggu pada periode t-1 (sebelumnya). Pengujian autokorelasi dilakukan dengan uji durbin-watson hitung (d) dengan nilai durbin-watson tabel, yaitu batas atas (du) dan batas bawah (dL) (Ghozali, 2016). Uji autokorelasi dalam penelitian ini dapat diperoleh nilai Durbin-Watson sebesar 1,768. Nilai ini dibandingkan dengan nilai Durbin-Watson pada tabel dengan tingkat signifikan 0,05 , jumlah sampel (n) 35, dengan jumlah variabel independen 5 $(\mathrm{k}=5)$, diperoleh nilai $\mathrm{dL}$ sebesar 1,1601 dan nilai dU sebesar 1,8029 dengan demikian nilai $\mathrm{d}=$ 2,105. Sesuai dengan kaidah keputusan Durbin-Watson, maka Jika dU $<\mathrm{d}<4-\mathrm{dU}(1,809<$ $2,105<2,839$ ) dapat disimpulkan bahwa maka tidak terjadi autokorelasi positif maupun negatif.

\section{Analisis Regresi Linear Berganda}

Tabel 3. Analisis Regresi Linear Berganda

\begin{tabular}{lrr}
\hline \multicolumn{1}{c}{ Model } & \multicolumn{2}{c}{ Unstandardized Coefficients } \\
\cline { 2 - 3 } & B & Std. Error \\
\hline (Constant) & 115,880 & 27,973 \\
PSAK & 0,996 & 0,137 \\
Audit Syariah & 0,541 & 0,406 \\
Pengawasan Syariah & $-0,650$ & 0,964 \\
ICG & $-1,694$ & 1,607 \\
Etos Kerja Islam & $-2,017$ & 0,703 \\
\hline
\end{tabular}

Sumber: Data sekunder setelah diolah, Tahun 2019 
Risky Yuniar Rahmadieni. Faktor-Faktor Yang Mempengaruhi Kualitas...

Berdasarkan data tabel 4.20 di atas, didapatkan persamaan multyple regresion sebagai berikut:

$\mathrm{Y}=\mathrm{a}+\mathrm{b}_{1} \mathrm{X}_{1}+\mathrm{b}_{2} \mathrm{X}_{2}+\mathrm{b}_{3} \mathrm{X}_{3}+\mathrm{b}_{4} \mathrm{X}_{4}+\mathrm{b}_{5} \mathrm{X}_{5}+\mathrm{e}$

$\mathrm{Y}=115,880+0,996 \mathrm{X}_{1}+0,541 \mathrm{X}_{2}+-0,650 \mathrm{X}_{3}+-1,694 \mathrm{X}_{4}+-2,017 \mathrm{X}_{5}+27,973$

a. Konstanta sebesar 115,880 menyatakan bahwa jika semua variabel bebas memiliki nilai (0), maka nilai variabel dependen (Kualitas penyajian laporan keuangan syariah) adalah sebesar 115,880 .

b. Nilai koefisien pernyataan standar akuntansi syariah $\left(\mathrm{X}_{1}\right)$ sebesar 0,996. Hal ini mengandung arti bahwa setiap kenaikan pernyataan standar akuntansi syariah satu satuan maka nilai variabel dependen (Kualitas penyajian laporan keuangan syariah) akan naik sebesar 0,996 dengan asumsi bahwa variabel bebas lain dari model regresi adalah tetap.

c. Nilai koefisien audit syariah $\left(\mathrm{X}_{2}\right)$ sebesar 0,541 . Hal ini mengandung arti bahwa setiap kenaikan pernyataan standar akuntansi syariah satu satuan maka nilai variabel dependen (Kualitas penyajian laporan keuangan syariah) akan naik sebesar 0,541 dengan asumsi bahwa variabel bebas lain dari model regresi adalah tetap.

d. Nilai koefisien pengawasan syariah $\left(\mathrm{X}_{3}\right)$ sebesar -0,650. Hal ini mengandung arti bahwa setiap kenaikan pernyataan standar akuntansi syariah satu satuan maka nilai variabel dependen (Kualitas penyajian laporan keuangan syariah) akan naik sebesar -0,650 dengan asumsi bahwa variabel bebas lain dari model regresi adalah tetap.

e. Nilai koefisien Islamic corporate governance $\left(\mathrm{X}_{4}\right)$ sebesar-1,694. Hal ini mengandung arti bahwa setiap kenaikan pernyataan standar akuntansi syariah satu satuan maka nilai variabel dependen (Kualitas penyajian laporan keuangan syariah) akan naik sebesar 1,694 dengan asumsi bahwa variabel bebas lain dari model regresi adalah tetap.

f. Nilai koefisien etos kerja Islam $\left(\mathrm{X}_{5}\right)$ sebesar -2,017. Hal ini mengandung arti bahwa setiap kenaikan pernyataan standar akuntansi syariah satu satuan maka nilai variabel dependen (Kualitas penyajian laporan keuangan syariah) akan naik sebesar -2,017dengan asumsi bahwa variabel bebas lain dari model regresi adalah tetap.

\section{Uji Parsial (Uji T)}

Tabel 4. Uji Parsial (Uji T) dan Uji Simultan (Uji F)

\begin{tabular}{lcccc}
\hline \multicolumn{1}{c}{ Model } & Koefisien Regresi & $\mathbf{t}$ & Sig. & F \\
\hline (Constant) & 115,880 & 4,148 & 0,000 & \\
PSAK & 0,996 & 7,724 & 0,000 & \\
Audit Syariah & 0,541 & 1,332 & 0,193 & \\
Pengawasan Syariah & $-0,650$ & 0,674 & 0,505 & 17,719 \\
ICG & $-1,694$ & 1,054 & 0,301 & \\
Etos Kerja Islam & $-2,017$ & $-2,870$ & 0,008 & \\
\hline
\end{tabular}

Sumber : Hasil olah data sekunder Tahun 2019

Penjelasan dari Tabel 5 langkah-langkah dalam penyajian hasil uji hipotesis secara parsial dalam penelitian ini adalah sebagai berikut:

Variabel Pernyataan Standar Akuntansi Syariah $\left(\mathrm{X}_{1}\right)$ memiliki nilai $\mathrm{t}_{\text {hitung }} 7,724>\mathrm{t}_{\text {tabel }}$ 1,699 dengan nilai probabilitas signifikansi sebesar 0,000. Signifikansi t lebih kecil dari $\alpha(0,05)$ maka $\mathrm{HO}$ ditolak dan $\mathrm{Ha}$ diterima. Berarti terdapat pengaruh signifikansi antara PSAK dengan kualitas penyajian laporan keuangan syariah. Peneliti didukung oleh penelitian Mawarid (2014) menyatakan bahwa penyusunan laporan keuangan pembiayaan Mudharabah (PSAK No.105) berpengaruh pada kualitas laporan keuangan BMT. Responden dalam penelitian ini ada sekitar $60.0 \%$ yang mengetahui tentang PSAK (Pernyataan Standar Akuntansi Syariah). Hal ini 
menunjukkan para karyawan memiliki potensi kemampuan untuk dapat menyelesaikan dalam proses penyusunan laporan keuangan berkualitas sesuai standar dengan PSAK.

Variabel Audit Syariah $\left(\mathrm{X}_{2}\right)$ memiliki nilai $t_{\text {hitung }}$ 1,332 $<t_{\text {tabel }}$ 1,699 dengan nilai probabilitas signifikansi sebesar 0,193. Signifikansi t lebih besar dari $\alpha(0,05)$ maka H0 diterima dan $\mathrm{Ha}$ ditolak. Berarti tidak terdapat pengaruh signifikansi antara audit syariah dengan kualitas penyajian laporan keuangan syariah. Peneliti menilai hal itu disebabkan karena memeriksa laporan keuangan syariah menggunakan pedoman audit secara umum, tidak ada pedoman audit syariah bagi koperasi syariah. Hal ini didukung penelitian oleh Kasim (2009), masalah utama yang dihadapi saat ini tidak ada pendukung pedoman audit syariah dalam menyusun kerangka audit syariah, Indonesia dan Malaysia tidak wajib menggunakan standar yang dikembangkan oleh AAOIFI. Sehingga kebanyakan laporan keuangan syariah menggunakan kerangka audit syariah, meskipun mayoritas responden merasa bahwa kebutuhan audit syariah memang berbeda dari audit konvensional.

Variabel Pengawasan Syariah $\left(X_{3}\right)$ memiliki nilai $t_{\text {hitung }} 0,674<t_{\text {tabel }}$ 1,699 dengan nilai probabilitas signifikansi sebesar 0,505. Signifikansi t lebih besar dari $\alpha(0,05)$ maka H0 diterima dan Ha ditolak. Berarti tidak terdapat pengaruh signifikansi antara pengawasan syariah dengan kualitas penyajian laporan keuangan syariah. Hal ini didukung oleh Rini (2014), bahwa peran Dewan Pengawas Syariah tidak signifikan terhadap pelaporan keuangan dikarenakan belum efektif mereview dan memeriksa laporan keuangan. Peneliti menilai hal ini disebabkan karena latar belakang pendidikan

Variabel Dewan Pengawas Syariah $\left(\mathrm{X}_{4}\right)$ yang tidak sesuai atau tidak berkompeten di bidang ekonomi maupun akuntansi syariah. Sehingga menyebabkan terjadinya kecolongan dalam mengawasi transaksi syariah, akibatnya laporan keuangan syariah tidak relevan. Hasil penelitian Hikmah Endraswati (207) mengungkapkan, latar belakang pendidikan Dewan Pengawas Syariah berpengaruh positif signifikan terhadap kualitas pengungkapan laporan keuangan.

Variabel Islamic Corporate Governance $\left(\mathrm{X}_{4}\right)$ memiliki nilai $\mathrm{t}_{\text {hitung }} 1,054<\mathrm{t}_{\text {tabel }}$ 1,699 dengan nilai probabilitas signifikansi sebesar 0,301. Signifikansi t lebih besar dari $\alpha(0,05)$ maka H0 diterima dan Ha ditolak. Berarti tidak terdapat pengaruh signifikansi antara Islamic corporate governance syariah dengan kualitas penyajian laporan keuangan syariah. Peneliti menilai hal itu disebabkan karena kurangnya transparansi dan keadilan yang seharusnya benar-benar disajikan dan diketahui laporan keuangan syariah sesuai dengan keadaan sebenarnya. Dikarenakan BMT tidak melakukan publikasi di website, anggota BMT hanya mengetahui laporan keuangan pada saat Rapat Anggota Tahunan.

Variabel Etos Kerja Islam $\left(\mathrm{X}_{5}\right)$ memiliki nilai $\mathrm{t}_{\text {hitung }}-2,870>\mathrm{t}_{\text {tabel }}$ 1,699 dengan nilai probabilitas signifikansi sebesar 0,008. Signifikansi t lebih kecil dari $\alpha(0,05)$ maka H0 ditolak dan Ha diterima. Berarti terdapat pengaruh signifikansi antara etos kerja Islam dengan kualitas penyajian laporan keuangan syariah. Hal ini didukung oleh penelitian Sudawaran (2017), bahwa implementasi etika kerja Islam terdapat pengaruh positif dan signifikan terhadap kualitas penyajian laporan akuntansi. Etika kerja Islam sangat berperan penting dalam menyusun laporan keuangan syariah. Karyawan kelima BMT tersebut mengakui dan menjalankan tugasnya dengan baik sesuai dengan prosedur SOP dan prinsip syariah.

\section{Uji F}

Penjelasan dari tabel 6 hasil uji $\mathrm{F}$ dapat diketahui bahwa nilai $\mathrm{F}_{\text {hitung }}$ sebesar 17,719 dan $\mathrm{F}_{\text {tabel }} 2,533\left(\mathrm{~F}_{\text {hitung }}>\mathrm{Ft}_{\text {abel }}\right)$ maka dapat disimpulkan bahwa variabel pernyataan standar akuntansi syariah $\left(\mathrm{X}_{1}\right)$, audit syariah $\left(\mathrm{X}_{2}\right)$, pengawasan syariah $\left(\mathrm{X}_{3}\right)$, Islamic corporate governance $\left(\mathrm{X}_{4}\right)$ dan etos kerja Islam $\left(\mathrm{X}_{5}\right)$ secara bersama-sama berpengaruh signifikan terhadap kualitas penyajian laporan keuangan syariah $(\mathrm{Y})$. 
Risky Yuniar Rahmadieni. Faktor-Faktor Yang Mempengaruhi Kualitas...

\section{Koefisien Determinasi $\left(\mathbf{R}^{2}\right)$}

Koefesien determinasi $\left(\mathrm{R}^{2}\right)$ adalah mengukur seberapa besar kemampuan model dalam menerangkan variasi variabel dependen. Nilai adjusted $\mathrm{R}^{2}$ sebesar 0,437 atau sebesar 4,37\%. Sedangkan $\mathrm{R}^{2}$ sebesar 0,753 atau 7,53 \%. Dengan demikian dapat disimpulkan bahwa 5,20\%, variabel kualitas penyajian laporan keuangan syariah $(\mathrm{Y})$ mampu diklasifikan oleh pernyataan standar akuntansi syariah $\left(\mathrm{X}_{1}\right)$, audit syariah $\left(\mathrm{X}_{2}\right)$, pengawasan syariah $\left(\mathrm{X}_{3}\right)$, Islamic corporate governance $\left(\mathrm{X}_{4}\right)$ dan etos kerja Islam $\left(\mathrm{X}_{5}\right)$. Sedangkan sisanya sebesar 0,247 atau 2,47\% dijelaskan oleh variabel-variabel lain di luar model.

\section{PENUTUP}

Berdasarkan hasil dan pembahasan penelitian ini mengenai sebagai berikut : Variabel pernyataan standar akuntansi syariah $\left(\mathrm{X}_{1}\right)$ berpengaruh terhadap kualitas penyajian laporan keuangan syariah (Y). Hipotesis 1 menyatakan bahwa,"semakin baik PSAK maka semakin baik kualitas penyajian laporan keuangan syariah", diterima. Variabel audit syariah $\left(\mathrm{X}_{2}\right)$ tidak berpengaruh terhadap kualitas penyajian laporan keuangan syariah (Y). Hipotesis 2 menyatakan bahwa,"semakin baik audit syariah maka semakin baik kualitas penyajian laporan keuangan syariah", tidak diterima. Variabel pengawasan syariah $\left(\mathrm{X}_{3}\right)$ tidak berpengaruh terhadap kualitas penyajian laporan keuangan syariah (Y). Hipotesis 3 menyatakan bahwa,"semakin baik pengawasan syariah maka semakin baik kualitas penyajian laporan keuangan syariah", tidak diterima. Variabel Islamic corporate governance $\left(\mathrm{X}_{4}\right)$ tidak berpengaruh terhadap kualitas penyajian laporan keuangan syariah (Y).Hipotesis 4 menyatakan bahwa,"semakin baik Islamic corporate governance maka semakin baik kualitas penyajian laporan keuangan syariah", tidak diterima.Variabel etos kerja Islam ( $\left.\mathrm{x}_{2}\right)$ berpengaruh terhadap kualitas penyajian laporan keuangan syariah $(\mathrm{Y})$. Hipotesis 5 menyatakan bahwa,"semakin baik PSAK maka semakin baik kualitas penyajian laporan keuangan syariah", diterima. Saran untuk penelitian selanjutnya adalah untuk dilakukan analisis statistik yang lebih mendalam dengan memperluas objek tempat penelitian dan menambah variabel apa saja yang dapat mempengaruhi kualitas laporan keuangan syariah.

\section{DAFTAR PUSTAKA}

Achmad Hizazi, Susfayetti dan Sri Rahayu. (2010). Analisis Penerapan Akuntansi Syariah Di BMT Al Ishlah Kota Jambi. Jumal Penelitian Universitas Jambi Seri Humaniora, ISSN 0852-8349, Volume 12, Nomor 2. Program Studi Akuntansi, Fakultas Ekonomi, Universitas Jambi.

Amrul Ikhsan dan Musfiari Haridhi. (2017). Penerapan Standar Akuntansi Keuangan Syariah Pada Koperasi Jasa Keuangan Syariah (Studi Pada Baitul Qiradh di Kota Banda Aceh). Jurnal Ilmiah Mahasiswa Ekonomi Akuntansi, ISSN 25811002, Volume 2 Nomor 3. Program Studi Akuntansi Fakultas Ekonomi dan Bisnis Universitas Syiah Kuala.

Hidayat Solikhul. Penerapan Akuntansi Syariah Pada BMT Lisa Sejahtera Jepara. (2013). Jurnal Dinamika Ekonomi dan Bisnis UNISNU Jepara. Volume 10 Nomor 2.

Hizazi Achmad, Susfayetti \& Sri Rahayu. (2010). Analisis Penerapan Akuntansi Syariah di BMT Al Ishlah Kota Jambi. Jurnal Penelitian Universitas Jambi Seri Humaniora. Volume 12, Nomor 2: ISSN 0852-8349.

Agustianto. 2008. Optimalisasi Dewan Pengawas Syariah, www.pesantrenvirtual.com.indeks.php/ekonomisyariah 
Agus Basuki. (2010). Akuntansi Baitul Mal Wa Tamwil (BMT) Arafah Solo (Perspektif Permyataan Standar Akuntansi Keuangan (PSAK) Syariah 2007). Skripsi, Jurusan Syariah (Muamalah) Universitas Muhammadiyah Surakarta.

Ali Mauludi AC. (2014). Akuntansi Syariah; Pendekatan Normatif, Historis Dan Aplikatif. Jurnal Akuntansi Syariah., Vol. 1 No. 1. LAIN Tulungagung.

Anindita Wahyu Aristyandini. (2013). Persepsi Akuntan Tentang Penerapan PSAK No. 101 Pada BMT Di Kabupaten Klaten. Skripsi. Fakultas Syariah dan Hukum. Universitas Islam Negeri Yogyakarta.

Baihaqi, Fadhilah, Nurcholisah. (2015). Pengarub Penerapan Standar Akuntansi Syariah Terhadap Pengelolaan Transaksi Kenangan Pada Bank Syariab (Studi Kasus Pada Bank Jabar Banten Syariab).

Dian Triyanti. (2008). Perlakuan Akuntansi Terbadap Bagi Hasil Bank Syariah Ditinjau Dari Sistem Pendanaan, Sistem Pembiayaan, Dan Laporan Keuangan Pada Bank Syariah Mandiri Cabang Surakarta. Skripsi, Fakultas Ekonomi. Universitas Muhammadiyah Surakarta.

Ghozali, Imam (2016). Aplikeasi Analisis Multivariete Dengan Program IBM SPSS 23 (Edisi 8). Cetakan VIII. Semarang : Badan Penerbit Universitas Diponegoro.

Ismail Puhi. (2013). Penerapan Akuntansi Keuangan Syariah Dalam Kinerja Keuangan Baitul Maal Wa Tamwil (BMT). Al-Mizan Vol. 9 No. 1 Juni 2013.

Hikmah Endraswati. (2017). Struktur Islamic Corporate Governance Dan Kualitas Pengungkapan Laporan Keuangan. IAIN Salatiga.

I.Gst Agung Ayu Rai Utami Handayani. (2017). Analisis Perbedaan Perilaku Etis Pelaku Akuntansi Dalam Etika Penyusunan Laporan Keuangan Satuan Kerja Perangkat Daerah Kabupaten Bandung. E-Jurnal Ekonomi dan Bisnis Universitas Udayana.

Qanita Mardiyah. (2015). Praktik Audit Syariah Di Lembaga Keuangan Syariah Indonesia. Sekolah Tinggi Ekonomi Islam SEBI.

Meilani Purwanti Dan Aceng Kurniawan. (2013). Meningkatkan Kualitas Laporan Keuangan Koperasi Melalui Penerapan Sistem Akuntansi Dan Kompetensi (Studi Pada Koperasi Di Kota Bandung). STAR-Study \& Accounting Reseach, Vol X, No. 3. STIE STEMBI.

Minarni. (2015). Konsep Pengawasan, Kerangka Audit Syariabdan Tata Kelola Lembaga Keuangan Syariah. Mahasiswa Magister Studi Islam, Program Pascasarjana, Fakultas Ilmu Agama Islam, Universitas Islam Indonesia.

Muzayyidatul Habibah dan Alfu Nikmah. (2016). Analisis Penerapan Akuntansi Syariah Berdasarkan Psak 102 Pada Pembiayaan Murabahah Di BMT SeKabupaten Pati. Jumal Ekonomi Syariah Volume 4, Nomor 1, P-ISSN: 2355-0228, E-ISSN: 2502-8316. Sekolah Tinggi Agama Islam Negeri (STAIN) Kudus, Jawa Tengah.

Mohammad Irham. (2012). Etos Kerja Dalam Perspektif Islam. Jurnal Substantia, Vol. 
Risky Yuniar Rahmadieni. Faktor-Faktor Yang Mempengaruhi Kualitas...

14, No. 1. Fakultas Ushuluddin Iain Ar-Raniry.

Muh Awal Satrio Nugroho. (2015). Urgensi Penerapan Islamic Corporate Governance di Baitul Maal Wat Tamwil. Prodi Manajemen STIE Widya Wiwaha.

Muchtar. 2004. Akuntansi Islam. Jakarta: Bumi Aksara.

IAI (2007). Pernyataan Standar Akuntansi Kenangan Penyajian Laporan Keuangan Syariah.

Rahmawati dan Suazhari. (2015). Pengaruh Pemahaman Manajer tentang Standar Akuntansi Keuangan Syariah dan Peran Dewan Pengawas Syariah terhadap Kualitas Laporan Keuangan BPRS di Aceh.

Rahman, Abdul Rahim Abdul. (2008).'Shari'ah Audit for Islamic Financial Services: The Needs and Challenges' Makalab dipresentasikan pada International Shari'ah ResearchAcademy for Islamic Finance (ISRA) Islamic Finance Seminar, Kuala Lumpur, 11 November 2008.

Rini. (2014). Pengaruh Penerapan Peran Komite Audit, Peran Dewan Pengawas Syariah dan Efektivitas Pengendalian Inetrnal Terhadap Kualitas Pelaporan Kenangan Pada Studi Empiris Bank Syariah Di Indonesia.

Rizal, Yaya, Aji Erlangga Martawireja dan Ahim Abdurahim. 2009. Akuntansi Perbankan Syariah Teori dan Praktek kontemporer. Salemba Empat, Jakarta.

Sri Dewi Anggadini. (2015). Perlunya Akuntansi Syariah di Lembaga Keuangan Syariah. Majalah Ilmiah Unikom, Vol 8 No.2. Program Studi Akuntansi Fakultas Ekonomi Unikom.

Sugiyono. 2005. Metode Penelitian Bisnis. Bandung: Alfabeta

Sugiyono. 2011. Metode Penelitian Kuantitatif, Kualitatif dan R\&D. Bandung: Afabeta

Sudarwan. (2017). Pengarub Etika Kerja Islami Terbadap Kualitas Penyajian Laporan Akuntansi: Self Esteem Sebagai Variabel Intervening (Studi Kasus pada Staf lapang Koperasi Syariah Benteng Mikro Indonesia).

Virginia Nur Rahmanti. (2012). Sebuah Kajian Mengapa Akuntansi Syariah Masih Sulit Tumbuh Subur Di Indonesia Jurnal Akuntansi \& Investasi Vol. 13 No. 2, halaman: 161-179. Fakultas Ekonomi dan Bisnis Universitas Brawijaya.

Widiana. (2017). Analisa Perkembangan Peraturan Dan Penerapan Akuntansi Syariah Di Indonesia. Jurnal Law and Justice Vol. 2 No. 1. Universitas Padjajaran. 